\title{
COMPREHENSIVE EDUCATION FOR THOSE CONCERNED WITH SPINAL CORD INJURY PATIENTS
}

\author{
By James M. Houston, M.D., F.R.C.P. (C) \\ Virginia Spinal Cord Injuries System, Woodrow Wilson Rehabilitation Center, \\ Fishersville, Virginia U.S.A.
}

Summary. The Commonwealth of Virginia has established a comprehensive programme for the management of the spinal cord injury (SCI) patients from the moment of injury through all aspects of rehabilitation into long-term follow-up. An average of 200 new patients are registered per year. A major emphasis of our programme has been the education of the patients and their relations and friends by means of group education conferences, patient and family follow-up contact, 'Family Days,' group lectures on selected topics, individual discussions, and discharge conferences. Audio-visual aids augment the programme. Patients are provided with printed literature on SCI for their own review and this is subsequently discussed with them.

We have worked with the Emergency Rescue Team on early management; and education on prophylaxis has been carried out in the school systems statewide. Public awareness of the problems of the physically handicapped has been encouraged. Through our follow-up clinic we are attempting to reach the community facilities and community physicians, making them aware of the problem of SCI and discussing with them facilities that are available to assist in their management.

While much has been accomplished we still have a long way to go.

Key words: Spinal cord injury; Education; Emergency care; Prevention.

ThE Virginia Spinal Cord Injury System is a comprehensive programme which is involved, from the moment of injury, through all aspects of rehabilitation including long-term follow up. Approximately 200 new patients are enrolled each year. Our prgramme is 'aggressive' involving all of the traditional personnel of acute therapy and of rehabilitation. Some aspects of our educational programme are discussed, which, whilst comprehensive, has retained a low budget profile.

\section{Introduction}

When a new spinal cord injury occurs, and is admitted to a Virginia hospital, by state law the Virginia Spinal Cord Injury System must be notified. With the approval of the attending physician contact is made with the patient and the family by a representative of the Registry (usually a local counsellor or Social Worker), leaving with them a packet of information which contains general information about spinal cord injury and draws their attention to the various agencies and services available. Reference is made to the ongoing programme which will be available to them if they and their physician elect to accept this advice.

Available literature:

Brochure Explanation of the Spinal Cord Injury Central Registry; Virginia Spinal Cord Injury System; Woodrow Wilson Rehabilitation Centre; Fishersville, VA. 
Booklet What You Should Know About Paraplegia; U.S. Department of Health, Education and Welfare.

Booklet An Introduction to Spinal Cord Injury; Paralyzed Veterans of America.

Letter Explanation of What Is the Medical Assistance Programme.

Pamphlet SSI for Aged, Disabled, and Blind People; U.S. Department of Health and Human Services, Social Security administration.

Pamphlet If You Become Disabled; U.S. Department of Health and Human Services.

Letter Services for Veterans.

Booklet Your Rights As A Disabled Person; U.S. Department of Health and Human Services Administration.

Pamphlet The Health Department's Consumer's Guide to Home Health Services; Virginia Department of Health.

Pamphlet An Investment in the Future-the Benefits of Hiring the Disabled; Virginia Department of Rehabilitation Services.

Forms and Leaflets Handicapped Parking Information.

\section{Patient and Family Education}

The majority of these patients are referred to our rehabilitation programme. Shortly after their admission to the rehabilitation unit a meeting is held with the various members of the rehabilitation team, who discuss the specific injury with the individual and orient them to the rehabilitation programme to be embarked upon. All of the traditional approaches for education are followed, each discipline working on a one-to-one basis in their particular area of expertise. In addition, we considered that there were many specific areas to be reviewed with a large patient volume. In order that there would be as few omissions as possible the 'Virginia Spinal Cord Injury Care and Teaching Manual' was written, and it serves as a guideline and reference book for each patient. It provides information on skin care, bowel management, bladder management, etc. At the end of each section a check list is provided. A member of staff then expands on the information provided, at the completion of which the check list is ticked off. Every effort is also made to educate the families of the patient.

In addition to individual teaching, a two-hour classroom session is held once a week, on an eight week rotating cycle. The topics covered are:

Living Independently.

Nutrition, Skin, Bowel, and Bladder Management.

Understanding How Others View Disability.

Social Skills Training.

Sexuality, Part I.

Sexuality, Part 2.

Exploration of Employment Opportunities Available for the Spinal Cord Injured. Taking Medication At Home.

Again we are attempting to increase the background knowledge of the condition. Each didactic session leaves ample opportunity for questions and group discussion, the lecturer offering expert guidance.

Once a month, a 'Family Day' is held, usually on a Saturday, when appropriate members of the family are invited to spend the day for general education, using films and discussions. 


\section{Community Involvement}

Return to the community is a very individual matter. In an attempt to facilitate the transition from the institutional setting to home and community life, a local support network or CADRE SYSTEM of some 46 successfully rehabilitated spinal cord injured patients has been developed, covering all aspects. In selecting CADRE members, the following eight criteria were used:

traumatic spinal cord injured;

knowledgeable about the process of spinal cord injury rehabilitation; interested in helping others;

personal assertiveness;

familiar with the community;

a low level of anxiety;

not depressed; and

not overly hostile

The assistance a Cadre member provides for a spinal cord injured client and family can take various forms, depending upon individual circumstances. Initially, Cadre members may provide information concerning the purchase of supplies, equipment and medications. In some cases they may provide the names of key local people in social and health agencies. They may advise clients and families about accessible housing or social and recreational opportunities in the community. As the relationship continues the Cadre may perform the function of a role model, demonstrating how to cope successfully in matters of daily living. The Cadre member is not the primary service provider, nor is he replacing the rehabilitation counsellor, or performing the function of established service agencies. To date, we are pleased with the good reports we are receiving on this programme, so much so that a 'Family Cadre' system is now in the early stages of development.

\section{Prevention}

Great emphasis is placed on prevention. In I968 our legislature enacted the Highway Safety Act providing an ambulance service, with minimal requirements regarding equipment and the training standards for personnel. Through our Spinal Cord Injury Project Director, and Officials of the State Department of Health, comprehensive workshops have been developed on 'the Preliminary Diagnosis and Emergency Transportation of Suspected Spinal Cord Injured.' The Emergency Medical Technicians (EMT) asked for more, therefore a training package was developed which consists of innovative approaches to the psychological training of the EMT with some tuition in anatomy and neurology, identification of head and neck injuries, and immobilization techniques. The presentation includes video-tapes, slides and audio-narration, and the presence of a physician, trained in trauma techniques, to answer questions of a special nature not covered in the presentation. This packet has been made available to other states as well as Medical School Libraries.

National figures for the past Io years showed that 70 per cent of victims of severe spinal cord injury were totally paralyzed upon arrival at the hospital emergency room. Recent figures indicate a decrease by half to 
30 to 40 per cent totally paralyzed on hospital arrival, due mainly to better care at the accident scene.

Since 1978 all editions of the Drivers Training Manual, a text for all would-be drivers in our state, have included information indicating what action should or should not take when coming upon the scene of an accident. This information has also been produced in a wallet-sized card and made available at the locations for driver's licence renewal and the purchase of state automobile tags. Cards bearing the same information are also distributed at highway rest stops throughout the state, in order to disseminate the information to out-of-state drivers.

Noting that 50 per cent of our patients were less than 25 years of age, a high school programme has been developed with a spinal cord injuredindividual and a member of our staff plus a film presentation. In 1979I980, I0,000 young people were shown this programme. Its strong acceptance warranted expansion. Thus in I98I-I982 a total student audience of 65,350 was reached with a 90 -minute presentation in the hospital 99 per cent of these students would recommend this programme to others.

With the interest generated by this programme local industry has requested a similar Spinal Cord Injury Prevention Programme for its employees as part of 'Summer Injury Prevention Programme on Off-the-Job Injuries,' and this project continues to expand.

Efforts have been made to increase public awareness of the causes and consequences of spinal cord injuries. Poster demonstrations are rotated through the city buses. Several interested TV stations offered air time to convey SCI Prevention messages, using our 'high school programme' format. This same format has been carried into the correctional facilities for young offenders. News releases on SCI Prevention Programme are promoted through newspaper and radio'stations, noting that Spinal Cord Injury is Forever!!!'

Films have been made of handicapped sports and these films are available for community interest groups. Our staff are frequently invited to speak and hold seminars for Public Health Nurses, Schools of Nursing, Medical Staff in acute hospitals, other allied health personnel and various community groups.

An 'architectural barriers' survey of all Virginia colleges and universities was conducted and published in a booklet, being circulated to high school guidance counsellors and Department of Rehabilitation Service field counsellors as a guide to working with the severely handicapped.

One of our latest ventures has been into 'Health Fairs' where booths are set up on specified days in local shopping malls. On these days various health-related groups check blood pressure, blood sugar, vision, etc. Many organizations such as the Cancer Society, Diabetes Society or Spinal Cord Injury System set up booths to further public information.

\section{Conclusion}

We have developed a very dynamic and aggressive approach to spinal cord injury, but we continue, to search for further innovative ways to be the educators of the patient, the family, and the community. 


\section{RÉSUMÉ}

L'Etat de Virginie a établi un programme compréhensif pour le traitement des malades qui souffrent d'une blessure de la moelle épinière (SCI) depuis le moment de la blessure à travers tous les aspects de la réhabilitation jusque dans l'étude ultérieure à longue échéance. On enregistre une moyenne de deux cents nouveaux malades SCI par an. Un point important souligné dans notre programme a été l'éducation des malades et de leurs parents et amis au moyen de conférences d'éducation de groupe, de contact ultérieur avec les malades et leur famille, de 'Jours familiaux', de conférences de groupe et de discussion sur des thèmes choisis, de discussions individuelles ainsi que de conférences visant la sortie de l'hôpital. Des aides audiovisuelles supplémentent le programme. On fournit les malades de littérature imprimée sur les SCI qu'ils doivent étudier eux-mêmes et qu'on discute plus tard avec eux.

Nous avons travaillé avec l'Equipe de sauvetage d'urgence sur le traitement entrepris sans tarder, et l'education dans le domaine de la prophylaxie a été entreprise dans les systèmes scolaires à travers l'état tout entier. On a également encouragé de la part du public une conscience des problèmes des personnes physiquement handicapées.

A l'aide de notre clinique d'étude ultérieure nous tentons de gagner l'accès aux facilités de la communauté ainsi qu'aux médecins de la communauté, en les rendant conscients du problème des SCI et en discutant avec eux les facilités qui sont disponibles pour les aider dans leur traitement. Tandis qu'on a beaucoup accompli nous avons enore beaucoup de chemin à parcourir.

\section{ZUSAMMENFASSUNG}

Der Staat Virginien hat ein umfassendes Programm für die Pflege der Pazienten mit Rückenmarkverletzung (SCI) aufgestellt, und zwar schon vom Augenblick der Verletzung, durch alle Aspekte der Rehabilitierung bis in die langfristige Nachbeobachtung. Man registriert durchschnittlich zweihundert neue SCI-Pazienten pro Jahr. Ein bedeutender Unterstreichungspunkt von unserer Programm ist die Erziehung auf diesem Gebiet von den Pazienten und ihren Verwandten und Freunden gewesen, und zwar durch Gruppenerziehungskonferenzen, durch weitergehenden Kontakt mit Pazienten und Familie, durch 'Familientage', durch Gruppenvorlesungen und Diskussion über ausgewählte Themen, durch individuelle Diskussionen und Entlassungskonferenzen. Audiovisuelle Hilfsmittel ergäzen das Programm. Die Pazienten werden mit gedruckter Litteratur über SCI versorgt, die sie studieren sollen, und diese wird später mit ihnen diskutiert.

Wir haben mit der Notrettungsmannschaft auf dem Gebiet der frühen Pflege gearbeitet; und man hat die Erziehung im Felde der Prophylaxe ebenfalls im Schulsystem den ganzen Staat hindurch ausgeführt. Man hat auch die Erkenntnis durch das Publikum der Probleme von den physisch Behinderten gefördert.

Durch unsere Nachbeobachtungsklinik versuchen wir, die Gemeinschaftsveranstaltungen und die Gemeinschaftsärzte zu erreichen, und sie dadurch mit den Problemen der SCI bekannt zu machen, und die zur Verfügung stehenden Veranstaltungen, die ihnen mit ihrer Pflege helfen sollen, mit ihnen zu diskutieren. Während man schon viel erlangt hat, haben wir noch eine ganz lange Strecke zu laufen.

\section{REFERENCE}

Wilson, C. \& Thompson, D., (Ed.) (1983). The Virginia Community Cadre Network: Community reintegration of persons with spinal cord injury. Rehabilitation Literature, 44, No. I-2. 